\title{
SOCJALIZACJA PROFESJONALNA NAUCZYCIELI NA STARCIE KARIERY ZAWODOWEJ — DRUGA STRONA MEDALU
}

\begin{abstract}
Professional socialization of novice teachers - the other side of the coin

This paper discusses the outcomes of the first stage of conducted qualitative research on professional socialization of novice teachers. The presented analysis refers to the transition period from the role of a student to that of an employee and uncovers the less well-known empirically side of the coin in teacher training with regards to professional socialization of novice teachers - the perspective of constructing one's professional path at the intersection of two cultures: the culture of academia and the workplace culture.
\end{abstract}

Keywords: professional socialization of novice teachers, transition period, transition, workplace culture

\section{Streszczenie}

$\mathrm{W}$ artykule zaprezentowano rezultaty pierwszego etapu prowadzonych badań dotyczących socjalizacji zawodowej nauczycieli na starcie kariery. Przedstawiona analiza odnosi się do okresu przejścia z roli studenta do roli pracownika i odsłania mniej rozpoznaną empirycznie w pedeutologii stronę medalu procesu socjalizacji zawodowej młodych nauczycieli - perspektywę konstruowania własnej ścieżki zawodowej na styku spotkania się dwóch kultur: kultury akademii i kultury miejsca pracy.

Słowa kluczowe: socjalizacja zawodowa nowicjuszy, okres przejścia, tranzycja, kultura miejsca pracy

\section{Wprowadzenie}

Przygotowanie akademickie powszechnie uważane jest za najważniejszy okres $\mathrm{w}$ formowaniu profesjonalnej tożsamości nauczycieli. Być może z tego powodu znakomita część refleksji teoretycznych oraz badań empirycznych w polskiej 
pedeutologii koncentruje się wokół problemów edukacji nauczycieli, z jednej strony poszukując przyczyn jej niskiej jakości, z drugiej formułując normatywne modele profesji, przedstawiane w postaci coraz bardziej wyrafinowanych katalogów kompetencji zawodowych nauczyciela.

Problematyka socjalizacji profesjonalnej, rozumianej jako długotrwały proces uczenia się w miejscu pracy, szczególnie na starcie kariery, jest w rodzimych badaniach obszarem zaniedbanym. Poza dość obszerną literaturą, głównie branżową, skupioną na procedurze awansu zawodowego w okresie stażu, empiryczne eksploracje dotyczące uwarunkowań procesu socjalizacji zawodowej nowicjuszy są nieliczne [Mazurkiewicz, 2007; Walczak, 2012; Grochowalska, 2014], a istniejące przedmiotem swoich zainteresowań czynią przede wszystkim diagnozę problemów dydaktycznych, wychowawczych, organizacyjnych, z jakimi borykają się młodzi nauczyciele rozpoczynający pracę zawodową.

Tymczasem, jak dowodzą liczne badania prowadzone nie tylko w krajach europejskich [Sabar, 2004; Schatz-Oppenheimer, Dvir, 2014; Storm, 2015; i in.], przejście $\mathrm{z}$ etapu edukacji akademickiej do świata pracy jest ogromnym wyzwaniem, które w zawodzie nauczycielskim, co podkreślają Päivi Tynjälä i Hannu L.T. Heikkinen [2011], jest jeszcze trudniejsze. Wchodzący do zawodu nauczyciel musi od pierwszych dni pobytu w szkole przejąć pełen zakres obowiązków i odpowiedzialność za swoją pracę, tak jak jego doświadczeni koledzy. Skutkuje to wieloma problemami mogącymi utrudniać efektywne działanie nauczyciela, do których zalicza się m.in. wysoki poziom stresu, poczucie braku sprawstwa i kompetencji, trudności w nawiązywaniu pozytywnych relacji z uczniami, rodzicami, gronem pedagogicznym, interesariuszami zewnętrznymi.

$\mathrm{W}$ artykule zaprezentowano rezultaty pierwszego etapu prowadzonych badań dotyczących socjalizacji zawodowej nauczycieli na starcie kariery. Ze względu na ograniczone ramy tekstu analiza odnosić się będzie do okresu przejścia z roli studenta do roli pracownika, odsłaniając mniej rozpoznaną empirycznie w pedeutologii stronę medalu procesu socjalizacji zawodowej młodych nauczycieli - perspektywę konstruowania własnej ścieżki zawodowej na styku spotkania się dwóch kultur: kultury akademii i kultury miejsca pracy. Pozostałe kategorie/ procesy wyłonione z danych empirycznych były już [Kędzierska, 2015] lub będą przedmiotem kolejnych publikacji.

\section{Nowicjusze — założenia i konstrukcja projektu badań}

W historii badań jakościowych, jak pisze Uwe Flick, można odnaleźć wiele interesujących historii dokumentujących oryginalne źródła zainteresowań badaczy, prowadzące do realizacji projektów badawczych od „bardzo osobistych doświadczeń, przez doświadczenia i okoliczności natury mikrospołecznej, aż po problemy w skali całego społeczeństwa, mające implikacje dla polityki społecznej”" [Flick, 2010: 45].

Geneza opisywanego w artykule projektu nie miała tak spektakularnego początku. Moje zainteresowania problematyką socjalizacji zawodowej nowicjuszy 
pojawiły się w trakcie realizacji projektu badawczego poświęconego karierom zawodowym nauczycieli. Podczas analizy materiału empirycznego zauważyłam, że w narracjach nauczycieli legitymujących się krótkim stażem pracy (do 5 lat) tzw. etap przejścia ze świata edukacji do świata pracy stanowił podstawowy kontekst dla objaśniania doświadczeń biograficznych, także spoza obszaru życia zawodowego. Potrzeba zrozumienia opisywanych przez startujących w zawodzie nauczycieli zjawisk, procesów, które ze względu na obszar problematyki badawczej projektu „Kariery zawodowe nauczycieli” zostały „,przesunięte” z głównego nurtu analiz, stała się impulsem do rozpoczęcia kolejnego, który roboczo nazwałam „Nowicjusze - proces stawania się nauczycielem”. Wykorzystanie do budowania prekoncepcji zgromadzonych w trakcie wcześniejszych badań danych empirycznych miało istotne implikacje teoretyczno-metodologiczne. Oznaczało w rezultacie ulokowanie projektu „Nowicjusze” w dotychczasowej ramie teoretyczno-metodologicznej, którą stanowiły teoria interakcjonizmu symbolicznego oraz konstruktywistycznej metodologii teorii ugruntowanej.

Interakcjonizm symboliczny ${ }^{1}$, jak pisze Krzysztof Tomasz Konecki, „koncentruje się głównie na kształtowanych symbolicznie ludzkich procesach poznawczych i widzi w tych procesach klucz do wyjaśniania i rozumienia ludzkiej rzeczywistości" [Konecki, 2000: 34, wyróżnienie oryginału]. Dzięki temu podejściu można spojrzeć na nie tylko na jednostkę, ale także na grupę „,z perspektywy relacji, jakie w niej zachodzą, i opisać ją także językiem tych relacji” [Chomczyński, 2008: 9]. Zastosowanie w badaniach perspektywy interakcyjnej umożliwia odkrywanie rzeczywistości kreowanej przez uczestników interakcji. Dzięki niej można spojrzeć na świat z perspektywy badanego, aby zrozumieć, jakie wartości przypisuje obiektom i procesom, jak jednostka przeżywa swoje doświadczenia. Nowicjusz, wchodząc do grupy profesjonalnej, nieustannie kreuje i negocjuje swoją wizję ,"profesjonalnego ja" i wizję rzeczywistości. Dzięki interakcjom, jakie nawiązuje w społecznym świecie szkoły, uzyskuje informacje nie tylko o aprobowanych sposobach działania, ale także takie, dzięki którym buduje podstawy swojej profesjonalnej tożsamości. Jego sądy o rzeczywistości i praktyki działania mają charakter interakcyjny i wytwarzane są toku nieustannego komunikowania.

Analiza doświadczeń i procesów, w jakich aktywnie uczestniczy jednostka, wytwarzanych na styku wielu interakcji, jest możliwa tylko poprzez wykorzystanie metodologii, w których badacz nie narzuca własnych interpretacji, ale podąża drogą wyłaniającą się w toku systematycznie zbieranych danych. Takie podejście jest typowe dla metodologii teorii ugruntowanej, która „,polega na budowaniu teorii (średniego zasięgu) w oparciu o systematycznie zbierane dane empiryczne" [Konecki, Chomczyński, 2012: 177]. Teoria wyłania się w trakcie prowadzonych

${ }^{1}$ Ze względu na niezwykle bogatą spuściznę symbolicznego interakcjonizmu nie jest możliwe dokonanie w tym miejscu jej satysfakcjonującej rekonstrukcji. Na potrzeby niniejszego tekstu zostaną zaakcentowane tylko te idee, które stanowią układ odniesienia projektu badań. Szerzej interakcjonizm symboliczny jest prezentowany w pracach tłumaczonych na język polski H. Blumera, A. Straussa oraz rekonstruowany w pracach socjologów, m.in. P. Chomczyńskiego, M. Czyżewskiego, E. Hałas, K.T. Koneckiego, G. Woronieckiej. 
badań terenowych $\mathrm{z}$ danych empirycznych i jest ściśle związana z procesem badawczym. Jednym z postulatów formułowanych przez twórcę teorii ugruntowanej, Glassera [Glasser, Strauss, 2009], jest ograniczanie prekonceptualizacji do niezbędnego minimum, tak aby badacz nie narzucał na odkrywane dane swoich wcześniejszych przedzałożeń. Dlatego badacze wykorzystujący teorię ugruntowaną wkraczają na teren badań, wyposażeni jedynie we wstępną siatkę pytań i pojęcia uczulające [Blumer 2007], które na początkowym etapie pracy pozwalają zachować badaczowi czujność/wrażliwość na wyłaniające się z danych zjawiska, a które bez tych pojęć mogłyby zostać przez niego pominięte.

$\mathrm{Na}$ etapie prekoncepcji sformułowałam dwa pytania, które zakreśliły obszar eksploracji badawczej:

1. Jakie wzory socjalizacji zawodowej dokumentują się w narracjach nauczycieli na starcie kariery zawodowej?

2. Jak przebiega proces formowania profesjonalnych ram tożsamości startujących w zawodzie nauczycieli na styku kultury akademii i miejsca pracy?

Pojęciami uczulającymi, które stały się kompasem wyznaczającym kierunek badań, były: socjalizacja zawodowa, proces przejścia, próg, kultura organizacyjna szkoły, stawanie się nauczycielem.

Jednocześnie z procesem zbierania bogatych danych (wywiady z nowicjuszami) i kodowania materiału empirycznego, zgodnie z logiką konstrukcji procesu badawczego konstruktywistycznej teorii ugruntowanej ${ }^{2}$ [Charmaz, 2009], dokonywałam przeglądu literatury dotyczącej procesu socjalizacji zawodowej nauczycieli, aby ulokować prekonceptualizację w przestrzeni teoretycznej, która na tym etapie pracy z danymi dostarczyłaby kategorii i pojęć do zrozumienia/objaśniania odkrywanych zjawisk i procesów oraz kontynuowania prac badawczych (logika doboru próby, kodowanie, teoretyczne pobieranie próbek).

\section{Ustalenia teoretyczne}

Przegląd rodzimej literatury przedmiotu dotyczącej problematyki startu zawodowego nauczycieli pozwolił dostrzec jej marginalność w obrębie dyskursów pedeutologicznych oraz zdominowanie „myśleniem awansowym”, które skupia uwagę badaczy przede wszystkim na katalogowaniu trudności, z jakimi w pierwszych miesiącach pracy muszą zmierzyć się nauczyciele, oraz (do)określaniu roli opiekuna stażu w procesie ich rozwoju zawodowego. Gromadząc stopniowo dane

${ }^{2}$ Proces badawczy w teorii ugruntowanej nie jest linearny. Ma charakter elastyczny, otwarty i interaktywny. Rozpoczyna się ,z chwilą wkroczenia w obszar, gdzie będą gromadzone dane. Badacz wyrusza w tę podróż wyposażony w dyscyplinarne pespektywy, kilka narzędzi i tymczasowych pojęć. Podróż przez teorię ugruntowaną może obrać różne kierunki w zależności od tego, dokąd zmierza badacz i dokąd zaprowadzi go jego analiza" [Charmaz, 2009: 23]. Proces pisania raportu ma emergentny charakter i pozostaje często w sprzeczności z pozytywistycznymi wymaganiami organizacji pracy naukowej. Badacze posługujący się metodologią teorii ugruntowanej podporządkowują strukturę i formę raportu wyłaniającym się kategoriom procesom i ideom, stąd w tekście mogą pojawiać się niejednoznaczności i pęknięcia. 
narracyjne, a następnie dokonując ich analizy i interpretacji, poszukując związków między wyłaniającymi się kategoriami i ich własnościami, zauważyłam także, że pojęcia immanentnie związane $\mathrm{z}$ aparatem pojęciowym pedeutologii, $\mathrm{tj}$. adaptacja zawodowa i awans zawodowy, nie przystają do doświadczeń badanych nauczycieli dokumentujących się w danych empirycznych. Mówiąc inaczej, próbując wykorzystywać kategorie startu zawodowego i adaptacji zawodowej do objaśniania procesu przejścia nowicjusza pomiędzy światem akademii a placówki oświatowej, w której został zatrudniony, nie mogłam odnaleźć w języku dyscypliny takich kategorii/pojęć, które uchwyciłyby dynamikę i złożoność tego procesu. Podobnie niefunkcjonalne, z punktu widzenia wypełniania/nasycania kategorii startu zawodowego, okazało się drugie z kluczowych pojęć pedeutologii - awans zawodowy. Awans rozumiany jest tu wyłącznie w kategoriach wzrostu i oznacza w przypadku startujących w zawodzie spełnianie stażowych wymogów formalnych. W polu semantycznym tej kategorii nie mieszczą się zjawiska opisywane przez początkujących nauczycieli, takie jak nieumiejętność „czytania” kultury grupy profesjonalnej, ambiwalencja w stosunku do własnych kompetencji, niemożność planowania ścieżki rozwoju zawodowego, poczucie stagnacji i/lub regresu, ograniczania kompetencji zawodowych, poczucie (przed) wypalenia zawodowego, konflikt pomiędzy własnymi oczekiwaniami i potrzebami a presją grupy zawodowej.

Warto podkreślić, że uwaga badaczy penetrujących empirycznie pola problemowe startu zawodowego nauczycieli nie obejmuje tak ważnego dla procesu socjalizacji profesjonalnej „okresu progu”, czyli etapu między zakończeniem formalnej edukacji a rozpoczęciem pracy w placówkach oświatowych. Tymczasem, jak dowodzą liczne badania prowadzone $w$ innych krajach, to, jaka jest (samo)ocena startowego kapitału kariery przyszłego pracownika, długość okresu poszukiwania zatrudnienia, wcześniejsze doświadczenia zawodowe, doświadczenia związane z wejściem w kulturę grupy profesjonalnej - to kluczowe predykatory pomyślnej socjalizacji zawodowej i profilaktyki rezygnacji przez młodych nauczycieli z zawodu [Guarino i in., 2006; Allen, 2009; Tynjälä, Heikkinen, 2011; Storm, 2015; i in.].

Konieczność przekroczenia ograniczeń aparatu pojęciowego pedeutologii i poszukiwanie w obszarze nauk społecznych takich kategorii, które pozwoliłyby rozwiązać problem nieprzystawalności języka dyscypliny do danych wyłaniających się z badań, spowodowały, że do analizy procesu przejścia, czyli etapu pomiędzy zakończeniem formalnej edukacji a rozpoczęciem pracy w placówkach oświatowych, wykorzystałam teorie/kategorie/pojęcia z zakresu ekonomii oraz psychologii i socjologii pracy: kapitał kariery [Bańka, 2007], proces tranzycji [Piróg, 2016], kultury organizacyjne [Hofstade, 2000], kotwiczenie w zawodzie [Grzymała-Kazłowska, 2013b], proces stawania się pracownikiem [Konecki, 2007], lepiej przystające do danych, złożonych z własności, które zostały dostrzeżone w toku analizy. 


\section{Procedura doboru próby}

Badanie procesu wchodzenia nowego pracownika do zakładu pracy, w którym nowicjusz nie tylko adaptuje się do wymogów pracy i kultury organizacyjnej, ale także jest przedmiotem praktyk wprowadzających (inicjujących) nowego adepta do pracy i do sieci pracowniczych stosunków społecznych [Konecki, 2007: 10], wymagało pozyskania do badań grupy nauczycieli w takiej fazie życia, w której doświadczaliby istotnej zmiany swojego statusu zawodowego przez wejście na rynek pracy po zakończeniu edukacji profesjonalnej nadającej im pełne, formalne kwalifikacje zawodowe. Ponieważ wejście na rynek pracy nie jest obecnie rozumiane, co podkreśla Danuta Piróg, jako jednorazowy akt podjęcia pracy, „lecz jako długi i rozciągnięty w czasie (trwający nierzadko do 30. roku życia) proces transformacji od młodzieńczej zależności do dorosłej niezależności finansowej” [Piróg, 2016: 146], a wyniki badań dotyczących rezygnacji z wykonywania zawodu $\mathrm{w}$ grupie nauczycieli wskazują 5 lat jako okres krytyczny dla formowania tożsamości zawodowej, do pierwszej fazy badań rekrutowani byli nauczyciele, którzy spełniali następujące kryteria: zatrudnienie (w pełnym lub niepełnym wymiarze godzin) w publicznej placówce oświatowej, staż pracy nie dłuższy niż 5 lat, posiadanie pełnych, formalnych kwalifikacji do wykonywania pracy na stanowisku zatrudnienia.

Pierwszych pięciu rozmówców, z którymi przeprowadziłam tematyczne wywiady biograficzne, włączyłam do badań, wykorzystując tzw. metodę kuli śnieżnej. Prowadzona analiza materiału empirycznego po każdym przeprowadzonym wywiadzie stawała się podstawą do wyodrębnienia kategorii analitycznych, w wyniku których decydowałam o zmianie logiki doboru próby. Dokonując porównań pomiędzy przypadkami, typowałam do badań kolejne osoby, stosując metodę przypadków kluczowych. Na przykład ze względu na to, że pierwszych pięciu nauczycieli informowało o niskiej ocenie startowego kapitału kariery, w dalszym etapie gromadzenia danych w terenie poszukiwałam rozmówców, którzy deklarowali wysoki poziom poczucia własnych kompetencji na starcie kariery. Dobór przypadków kluczowych w badaniach jakościowych pozwala na dokonywanie stopniowej i ciągłej komparacji i nasycanie wyłonionych z danych kategorii, pojęć, procesów.

Wywiady za zgodą badanych były nagrywane na dyktafon i po dokonaniu transkrypcji budowały korpus materiału empirycznego. Analiza prezentowana $\mathrm{w}$ artykule ${ }^{3}$ odnosi się do jednej z wyłonionych kategorii - procesu tranzycji.

${ }^{3}$ Projekt „Nowicjusze”, który rozpoczęłam w 2015 roku, nie został jeszcze zakończony. Prezentowana analiza dotycząca procesu tranzycji opiera się na danych pochodzących z próbki 15 tematycznych wywiadów biograficznych. Kategoria tranzycji uzyskała teoretyczną wystarczalność, kolejne przeprowadzone wywiady nie wnosiły nowych teoretycznych spostrzeżeń i nie ujawniły nowych własności. 


\section{Studia i po studiach...}

Przejście z systemu edukacji na rynek pracy, jak wynika z wypowiedzi badanych młodych nauczycieli, jest sytuacją trudną do zaplanowania i niezwykle frustrującą. W minionym systemie odpowiedź na pytanie, jak stać się nauczycielem, jak budować swoją zawodową przyszłość, była dość przejrzysta. Współcześnie proces upowszechnienia edukacji na poziomie wyższym spowodował, że wejście na rynek pracy w zawodzie nauczyciela jest jednym z najtrudniejszych zadań w okresie wczesnej dorosłości i coraz częściej składa się z kilku mniej lub bardziej udanych prób wejścia do zawodu/zatrudnienia, które układają się w patchworkowy wzór kariery [Kędzierska, 2012].

Obroniłem dyplom i złożyłem kilka ofert pracy. W sierpniu poproszono mnie na rozmowę kwalifikacyjną i zostałem zatrudniony. Nawet się zdziwiłem, że tak szybko poszło, bo tyle się nasłuchałem o tym, jak ludzie przez kilka lat nie mogą niczego dostać, a tu prawie od razu (3) ${ }^{4}$, ale to tylko na rok i tylko na pół etatu [N/M: 1] $]^{5}$.

Problemy zatrudnienia młodych nauczycieli wynikają nie tylko, jak dowodzą wypowiedzi nowicjuszy, z braku ofert pracy, ale także z tego, że corocznie na dość wysyconym już przez specjalistów oświatowym rynku pracy pojawiają się osoby dysponujące podobnym kapitałem edukacyjnym. W związku z tym coraz częściej pracodawcy modyfikują kryteria rekrutacji, a ocena potencjalnego pracownika dokonywana jest $\mathrm{z}$ uwzględnieniem innych rodzajów kapitału kariery. Jednak w obliczu dynamicznych zmian na rynku pracy niezwykle trudno jest, szczególnie w okresie poprzedzającym podjęcie pracy zawodowej, antycypować, który rodzaj kapitału kariery powinien dominować w fazie edukacji, aby zwiększał szansę na skuteczne wejście na rynek pracy.

W czasie studiów to ja robiłam dużo wiele kursów, szkoleń i pracowałam też w kole naukowym, wszystko, aby w cv było co wpisać, a nie tylko, że mam ten dyplom [N/K: 3].

Trudności na rynku pracy skutkują często radykalnymi decyzjami i zmianą planów życiowych podejmowanych często wbrew wcześniejszym zamierzeniom, często na bardzo wczesnym etapie życia.

Byłam na praktyce w tej placówce i dyrektorka zaproponowała mi pracę od razu na pełen etat, pod warunkiem że zacznę natychmiast. A ja myślałam, że najpierw licencjat, potem magisterka no::: to było bardzo trudne, co zrobić, ale jak jest praca,

${ }^{4}$ Zastosowałam system notacji Jefferson, w którym liczba w nawiasie wskazuje, ile sekund trwała przerwa w wypowiedzi, a liczba dwukropków po głosce lub sylabie określa orientacyjny czas trwania przeciągnięcia tej głoski lub sylaby w czasie mówienia.

${ }^{5}$ Oznaczenia przy notach to kody identyfikacyjne stosowane w badaniach, $\mathrm{np}$. $\mathrm{N}$ - nauczyciel, $\mathrm{M}$ - mężczyzna, 1 - numer kolejny wywiadu. 
to trzeba brać, a studia, no::: (3) są zaoczne, i tak zrobiłam, choć nigdy nie sądziłam, że to, to w takim tempie [N/K: 6].

Analiza procesu przejścia/tranzycji rozumianego jako „proces wkraczania na rynek osób kończących wybrany szczebel edukacji odbywający się głównie w wieku 15-24 lat, kiedy jednostki w sposób nasilony rozwijają swoje umiejętności, które mają powodować, iż staną się one produktywnym członkiem społeczeństwa" [Piróg, 2013: 131] i dokumentującego się w wypowiedziach badanych pozwoliła na identyfikację trzech ścieżek przejścia w badanej grupie nauczycieli. Ścieżka pierwsza to tzw. udana tranzycja, czyli uzyskanie zatrudnienia w publicznej placówce oświatowej w pełnym wymiarze czasu pracy z możliwością realizacji stażu zawodowego w okresie nie dłuższym niż pół roku po uzyskaniu dyplomu ukończenia studiów. Ścieżka druga to tzw. tranzycja wrażliwa, charakteryzująca się okresem wydłużania edukacji na poziomie wyższym na studiach III stopnia i równoległym zatrudnieniu (w różnych formach), często poza systemem oświaty. Ścieżka trzecia to tranzycja niepewna, której cechą dominującą jest albo długi okres poszukiwania zatrudnienia zgodnego z formalnymi kwalifikacjami, albo obarczone ryzykiem pozyskanie pracy niesatysfakcjonującej lub niestabilnej.

Opisywane wzory przebiegu procesu przejścia dokumentują nasilanie się w profesji nauczycielskiej zjawiska tzw. opóźnionej tranzycji [Piróg, 2016], które niesie ze sobą poważne konsekwencje biograficzne i profesjonalne. Niemożność uzyskania pracy i pełnego uniezależnienia się ekonomicznego po ukończeniu studiów wyższych skutkuje odraczaniem innych typowych dla okresu wczesnej młodości tranzycji (założenie rodziny, posiadanie dzieci, zakup mieszkania i.in.).

Udało mi się znaleźć stancję tańszą niż akademik! Ja jestem sam, nie mam dużych potrzeb, to z tego pół etatu daje się jakoś wyżyć. Szału nie ma, ale radzę sobie [N/M: 1].

Efektem odraczanych tranzycji są także, jak wynika z analizy wypowiedzi badanych, decyzje przedłużania okresu edukacji (kolejne kierunki/specjalności, studia na poziomie III stopnia):

W grudniu zadzwonił do mnie mój dawny nauczyciel, który zaproponował mi pracę za niego w czasie jego rocznego urlopu zdrowotnego. Znał mnie dobrze, bo chodziłem do tej szkoły i on wiedział, że jestem aktualnie na studiach doktoranckich i co sobą reprezentuję. Dlatego rekomendował mnie dyrektorowi na to zastępstwo. Pracuję na cały etat, ale bez stażu. To jest zastępstwo, tylko na rok, ja jestem na studiach doktoranckich i na razie to chcę robić. Nauczyciel, co go zastępuję, wróci po roku i nie ma możliwości, żebym mógł tu pracować dalej [N/M:11].

Skutkiem jest także szereg konsekwencji natury psychologicznej, m.in. narastająca pasywność i lęk przed konfrontacją z realiami rynku pracy, zaniżanie oceny własnych kompetencji zawodowych, poczucie krzywdy, niesprawiedliwości i in.: 
Ja napisałam i rozesłałam tych CV mnóstwo i co (5) bez odpowiedzi. Jak się nie ma znajomości, to wie Pani jak jest (3), ja w końcu znalazłam tę pracę zupełnie przez przypadek [N/K: 9].

Tymczasowość i płynność zatrudnienia, tak charakterystyczne dla patchworkowego wzoru kariery, przynoszą wiele konsekwencji, głównie negatywnych. Zatrudnienie w niepełnym wymiarze czasu pracy, etat łączony (praca w kilku szkołach, aby uzyskać pełność etatu), zatrudnienie na stanowisku nieodpowiadającym kwalifikacjom (absolwentka polonistyki zatrudniona w świetlicy, bibliotece itp.), zatrudnienie w krótkiej perspektywie czasowej (na rok, semestr, kilka miesięcy) blokują proces udanej tranzycji zawodowej początkujących nauczycieli. W wypowiedziach badanych nowicjuszy dokumentują się przede wszystkim problemy z zaangażowaniem się w wykonywaną pracę, brakiem identyfikacji z grupą odniesienia, trudności adaptacyjne w rozbieżnych/sprzecznych wzorcach kultury organizacyjnej, niemożność planowania własnej ścieżki kariery zawodowej, poczucie utraty kompetencji.

To jest już moja trzecia szkoła. Licząc te dwa lata, kiedy pracowałam w branży telekomunikacyjnej tuż po studiach, już pięć lat, i dopiero robię staż w tej szkole, ale i tak nie będę tu pracować po stażu, bo jestem na zastępstwie. Mam nadzieję, że w sąsiedniej miejscowości uda mi się załapać, bo jedna Pani idzie od września na urlop zdrowotny. Co dalej, zobaczymy [N/K: 12].

Przejście ze świata szkoły do świata pracy, jak wynika z przeprowadzonych badań z początkującymi nauczycielami, staje się, tak jak i w innych profesjach, coraz bardziej złożone i niepewne. Systematyczne pogarszanie się sytuacji na oświatowym rynku pracy powoduje szukanie rozwiązań zastępczych, które oddalają absolwentów studiów pedagogicznych od pracy w wyuczonej profesji. Sytuacja ta nie tylko utrudnia jakość procesu socjalizacji zawodowej startujących w zawodzie, ale ma, co warto podkreślić, wymiar strat ekonomicznych (koszty edukacji nauczycielskiej) i społecznych (tzw. stacja widmo, bezrobocie młodych wykształconych osób).

\section{Efekt progu, czyli socjalizacja zawodowa nowicjuszy w kulturze miejsca pracy}

Proces tranzycji to nie tylko okres poszukiwania pracy i jednorazowego aktu jej podjęcia - to długi i rozciągnięty w czasie proces dochodzenia do osobistej i zawodowej niezależności. Dla rozpoczynających pracę zawodową nauczycieli to czas formowania ram profesjonalnej tożsamości, który dokonuje się w wyniku zderzenia się dwóch światów: świata jednostki, jej wartości, celów, wyobrażeń i oczekiwań zawodowych oraz świata kultury organizacyjnej szkoły.

Pierwszy rok pracy określany był przez badanych startujących w zawodzie jako „trudny do ogarnięcia” [N/K: 2]. Przywoływane w narracjach wydarzenia 
kolejnych dni, tygodni i miesięcy po rozpoczęciu pracy dokumentują proces socjalizacji zawodowej, w którym w pierwszym okresie po zatrudnieniu dominuje potrzeba znalezienia punktów odniesienia/kotwic, które pozwoliłyby zlokalizować nowicjuszom ich miejsce w nowej sytuacji i dokonać transformacji tymczasowej tożsamości, którą nadała grupa profesjonalna. Celem zakotwiczania w nowej kulturze jest potrzeba osiągnięcia relatywnej, psychospołecznej stabilności w otaczającej jednostkę płynnej, złożonej i nieznanej rzeczywistości. Wykorzystywane przez startującego w zawodzie nauczyciela kotwice pozwalają mu zlokalizować, jak pisze Aleksandra Grzymała-Kazłowska, „swoje «miejsce w świecie», upostaciowić swoje poczucie istnienia oraz dają podstawę psychologicznego i społecznego funkcjonowania" [Grzymała-Kazłowska, 2013a: 3], co jest niezbędne do dalszego funkcjonowania i intensyfikowania procesu uczenia się zawodu w miejscu pracy.

Wśród badanych nauczycieli zidentyfikowałam trzy odmienne typy zakotwiczenia: przez naśladownictwo, w rodzinnych zobowiązaniach i pozycji profesjonalnej oraz poprzez wysoką samoocenę startowego kapitału kariery [Kędzierska, 2015].

Zakotwiczenie poprzez naśladowanie dokonuje się przez prostą adaptację do kultury grupy profesjonalnej. Punktem oparcia dla startującego w zawodzie staje się wówczas „mądrość pokoju nauczycielskiego”. Nowicjusz umiejscawia się w grupie nauczycieli poprzez kopiowanie zachowań, definicji sytuacji, zasad, norm preferowanych przez członków grupy profesjonalnej, które identyfikuje w toku wielu codziennych interakcji.

Ja to na początku podpatrywałam, co robią inni, i starałam się robić tak jak oni. Jak miałam problem, to pytałam moją opiekunkę stażu i ona mi dokładnie wyjaśniała, co trzeba robić [N/K: 2].

Drugi typ zakotwiczenia wynikał ze zjawiska, które można nazwać kotwiczeniem w rodzinnych zobowiązaniach i pozycji profesjonalnej. Dla nowicjuszy pochodzących z rodzin nauczycielskich socjalizacja zawodowa i proces wejścia do zawodu w dużej mierze rozpoczęły się już w okresie socjalizacji pierwotnej, a wejściu w rolę nauczyciela towarzyszyła stała możliwość sięgania do profesjonalnych doświadczeń środowiska socjalizacji.

@Nauczycielką zostałam, ponieważ moja mama była nauczycielką@6, i tu naprawdę nie mam co wymyślać, że jakieś pasje były, bo kończąc liceum, to nie miałam żadnych planów, nie wiedziałam, co mam ze sobą zrobić, no i mama mi kazała zdawać na nauczanie początkowe [...] Studia niewiele mnie nauczyły, wszystko, co $\mathrm{w}$ tej chwili mam, co umiem i wykorzystuję, nauczyłam się od mojej mamy [N/K: 6].

Trzeci typ zakotwiczenia to ocena startowego kapitału kariery. Punktem oparcia dla młodego nauczyciela jest tutaj przekonanie o wysokich osobistych

6@@...@-znaki transkrypcyjne oznaczające emocjonalną wypowiedź narratora,w tym wypadku frazę wypowiedziana ze śmiechem. 
kompetencjach zawodowych i pragnienie realizacji wcześniej wyobrażonego projektu siebie w roli zawodowej.

I tak jakoś przez studia przebrnąłem, @mając na pieńku z Panią od dydaktyki@. Pierwsze doświadczenia w pracy to były rzeczywiście trudne, bo jak w tak nietypowym momencie zostałem zatrudniony, a ta śmietanka nauczycielska to, no, jak by to powiedzieć, nie była skora do współpracy, taki brak zainteresowania i życzliwości, to doświadczyłem też na praktykach, na ale z moim zapałem do pracy i wszystkimi ideami, które się rodziły w głowie, to::: te pierwsze lekcje były rzeczywiście trudne [N/M: 11].

Znajdowanie punktów referencyjnych w nowej kulturze jest wynikiem interakcji, w jakie wchodzi nowicjusz na styku kultur: organizacyjnej miejsca pracy i kultury edukacyjnej, w której konstruował podstawy własnego profesjonalizmu. Jak wynika z analizy doświadczeń okresu progu, proces socjalizacji zawodowej badanych przebiegał w odmiennych kulturach organizacyjnych. Analizując fragmenty narracji poświęcone sposobom organizacji placówek, w których byli/są zatrudnieni badani, trudno jest precyzyjnie konstruować przejrzyste typologie. Odwołując się jednak do klasyfikacji kultur organizacyjnych Charlesa Handy'ego, można powiedzieć, że socjalizacja zawodowa badanych w okresie tzw. progu przebiegała w kulturach, których kontinuum stanowiły kultura roli i kultura władzy, z tym że w różnych szkołach nasilenie cech poszczególnych kultur było odmienne.

W kulturze roli każdy jej członek ma jasno zdefiniowane: rolę, zadania, miejsce w strukturze, ,gdyż uznaje się je za przyczynę stabilizacji i równowagi organizacji. Role zastępowane są niekiedy systemem struktur oraz procedur. Ważne jest jasne ich określenie w przepisach i zasadach" [Furmanik, 2012: 117]. W kulturze władzy natomiast priorytetem jest realizacja aspiracji kierowników, a zarządzanie organizacją sprawowane jest w sposób dyrektywny, z wykorzystaniem specyficznego dla danej organizacji systemu wzmocnień (nagród i kar). Istotnymi cechami obu tych kultur jest koncentracja na osiąganiu partykularnych lub stanowionych przez władzę, ale nie wspólnych i podzielanych przez grupę celów i wartości.

Stawanie się profesjonalistą w kulturach nacechowanych brakiem współpracy powoduje, że nauczycielowi wchodzącemu do organizacji przypisuje się tymczasowy status tożsamości. Z wypowiedzi nauczycieli wyłania się pewna prawidłowość: im bardziej członkowie organizacji są wobec siebie nastawieni rywalizacyjnie, a ich działania nie są skierowane na współdziałanie, tym częściej nowicjusz otrzymuje etykietę obcego.

Obcy to osoba nienależąca do jakiejś grupy, kręgu ludzi, spraw, ktoś pochodzący z odmiennego, kulturowo nieznanego świata, kto nie został jeszcze przez nas dookreślony. Obcość jest postrzeganą negatywnie innością, wobec której należy zachować dystans lub ją ignorować.

Ja nie przejmowałam się tym, co się tam dzieje [w pokoju nauczycielskim - H.K.], wchodziłam tylko tyle, ile było potrzeba, zostawić swoje rzeczy, dziennik, i jechałam dalej, długo nie znałam nazwisk i teraz też nie wszystkie [znam - H.K.] [N/K: 3]. 
Transformacja tożsamości obcego, jak wynika z doświadczeń badanych nauczycieli, dokonuje się zazwyczaj poprzez naśladowanie, odwoływanie się do aprobowanych wzorców zachowania i postępowania w grupie nauczycieli. Zjawisko to wyjaśnia, jak sądzę, szybką i bezrefleksyjną adaptację wielu nowicjuszy do transmisyjnej kultury organizacyjnej szkoły, pomimo wcześniejszych deklaracji i przekonań.

Niezwykle interesującym wzorem tożsamościowym, która wyłania się z doświadczeń nauczycieli realizujących kariery patchworkowe, jest tożsamościowy wzór migranta. $\mathrm{Z}$ braku możliwości zatrudnienia w pełnym wymiarze godzin w jednej placówce nauczycielom, którzy łączą pracę w kilku szkołach lub pracują w niepełnym wymiarze godzin, trudno jest wyznaczyć punkty odniesienia, wokół których nowicjusz dokonywałby transformacji nadanej przez grupę tożsamości. Pejoratywny wydźwięk określenia, pojawiający się w narracjach badanych, sugeruje, że migrowanie w zawodzie nauczycielskim, choć coraz częstsze, nie jest czynnością „,normalną”, że standardem wciąż jest poszukiwanie „oswojonej szkoły” i „przywiązanie” do niej.

W kulturach, w których istnieje współpraca (nawet w formie ograniczonej), lub gdy startujący w zawodzie nauczyciel dość szybko w okresie progu znajduje dla siebie grupę odniesienia, jego proces socjalizacji zawodowej przebiega według typowego wzoru debiutanta. Stopniowo rozpoznaje zasady funkcjonowania organizacji i aktywnie, mogąc liczyć na wsparcie członków grupy, włącza się w realizację jej celów.

Ja miałem szczęście, bo razem ze mną w tym samym roku przyjęto też na rok kilku innych nauczycieli i my dość szybko się ze sobą poznaliśmy i po szkole też, bo to grupa osób lubiąca rowery, to nas zbliżyło i ja nie czułem się jakoś tak, że ja nie mam z kim porozmawiać, zapytać [N/M: 1].

Wyłonione z wyniku analizy wzory socjalizacji zawodowej na progu wskazują na niezwykle ważny wymiar procesu stawania się nauczycielem, tj. wymiar uczenia się profesji w miejscu pracy. Mówiąc inaczej, to, jak będzie przebiegać socjalizacja zawodowa początkującego nauczyciela, zależne jest nie tylko od poziomu jego akademickiego przygotowania, ale także od tego, w jakiej kulturze organizacyjnej będzie się ona odbywać. Jakość interakcji socjalizacyjnych, w jakie wchodzi młody nauczyciel, w ogromnym stopniu wyznacza jego dalszą drogę zawodową.

\section{Konkluzja}

Dotychczasowa eksploracja procesu socjalizacji zawodowej nowicjuszy w okresie przejścia wygenerowała więcej pytań niż odpowiedzi i - co zrozumiałe - nie pozwala na formułowanie końcowych wniosków oraz teoretyczne uogólnianie wyłonionych kategorii. Sądzę jednak, że rezultaty analizy materiału empirycznego na tym etapie badań pozwalają na kilka ostrożnych spostrzeżeń i sugestii. 
Przejście między światem akademii i światem pracy w zawodzie nauczycielskim generuje te same problemy, które dotyczą absolwentów niemal wszystkich wyższych uczelni. Tymczasowość, patchworkowe kariery zawodowe, opóźnione tranzycje to zjawiska, które domagają się nie tylko uwagi polityków i ekonomistów, ale w przypadku zawodu nauczyciela także pogłębionej refleksji pedeutologicznej. Dyskusja o zmianie systemu kształcenia, w której decyzje o jakości kapitału kariery podejmowaliby sami studenci, elastycznie konstruując własne ścieżki edukacyjne, powinna stać się priorytetowym zadaniem, zarówno dla polityków oświatowych, jak i środowisk badaczy edukacji.

Na jakość i przebieg socjalizacji zawodowej nauczycieli na starcie kariery, jak wynika z analizy doświadczeń biograficznych badanych, wpływa nie tylko poziom kompetencji profesjonalnych, które posiada nowicjusz, ale w dużej mierze także kultura organizacyjna miejsca pracy. Nie jest możliwe, aby w szkołach „,zadekretować" kulturę współpracy, stąd warto byłoby organizować, tak jak jest to w innych krajach, systemy wsparcia dla młodych nauczycieli poza środowiskami miejsca zatrudnienia, które umożliwiałyby nowicjuszom transformowanie nadanych im w organizacjach tymczasowych tożsamości w bardziej świadomy sposób i we wspierającym otoczeniu.

\section{Bibliografia}

Allen. J.M. (2009), Valuing Practice over Theory: How Beginning Teachers Re-orient Their Practice in the Transition from the University to the Workplace, „Teaching and Teacher Education", 25.

Bańka A. (2007), Psychologiczne doradztwo karier, Stowarzyszenie Psychologia i Architektura, Poznań.

Blumer H. (2007), Interakcjonizm symboliczny. Perspektywa i metoda, tłum. G. Woroniecka, Zakład Wydawniczy „Nomos”, Kraków.

Charmaz K. (2009), Teoria ugruntowana. Praktyczny przewodnik po analizie jakościowej, tłum. B. Komorowska, Wydawnictwo Naukowe PWN, Warszawa.

Chomczyński P. (2008), Mobbing w pracy z perspektywy interakcyjnej. Proces stawania się ofiara, Wydawnictwo Naukowe Uniwersytetu Łódzkiego, Łódź.

Czyżewski M. (2013), Socjologia interpretatywna i metoda biograficzna: przemiana funkcji, antyesencjalistyczne, wątpliwości oraz sprawa krytyki, „Przegląd Socjologii Jakościowej", 9(4).

Flick U. (2010), Projektowanie badania jakościowego, Wydawnictwo Naukowe PWN, Warszawa.

Furmanik M. (2012), Kultura organizacyjna w szkołach różnych krajów, „Zarządzanie Publiczne", 1(21).

Guarino C.M., Santibañez L., Daley G.A. (2006), Teacher Recruitment and Retention: A Review of the Recent Empirical Literature, „Review of Educational Research”, 76.

Glasser B., Strauss A. (2009), Odkrywanie teorii ugruntowanej. Strategie badania jakościowego, tłum. M. Gorzko, Zakład Wydawniczy „Nomos”, Kraków. 
Grochowalska M. (2014), Dylematy nowicjusza. Konteksty stawania się nauczycielem edukacji przedszkolnej, „Edukacja Elementarna w Teorii i Praktyce”, 31(1).

Grzymała-Kazłowska A. (2013a), Zarys koncepcji społecznego zakotwiczenia. Inne spojrzenie na tożsamość, adaptację i integrację imigrantów, „Kultura i Społeczeństwo”, 57(3).

Grzymała-Kazłowska A. (2013b), Od tożsamości i integracji do społecznego zakotwiczeniapropozycja nowej koncepcji teoretycznej, Warszawa CMR Working Paper, 64(122), http:// www.migracje.uw.edu.pl/ [dostęp: 12.05.2013].

Hałas E. (2006), Interakcjonizm symboliczny. Społeczny kontekst znaczeń, Wydawnictwo Naukowe PWN, Warszawa.

Harrison J.R., Carroll G.R. (2006), Culture and Demography in Organizations, Princeton University, http://press.princeton.edu/chapters/s8183.pdf [dostęp: 12.04.2015]

Hofstade G. (2000), Kultury i organizacje. Zaprogramowanie umysłu, tłum. M. Durska, PWE, Warszawa.

Kędzierska H. (2012), Kariery zawodowe nauczycieli. Konteksty - wzory - pola dyskursu, Wydawnictwo Adam Marszałek, Toruń.

Kędzierska H. (2015), Novice Teachers: The Process of "Anchoring” in the Teaching Profession, „Forum Oświatowe”, 2(54).

Konecki K.T. (2000), Studia z metodologii badań jakościowych. Teoria ugruntowana, Wydawnictwo Naukowe PWN, Warszawa.

Konecki K.T. (2007), Nowi pracownicy a kultura organizacyjna przedsiębiorstwa. Studium folkloru fabrycznego, „Przegląd Socjologii Jakościowej” 3(1), Monografie. Seria „Stawanie się”, http://www.qualitativesociologyreview.org/PL/volume3_pl.php [dostęp: 25.05.2016].

Konecki K.T., Chomczyński P. (2012), Słownik socjologii jakościowej, Wydawnictwo Difin, Warszawa.

Mazurkiewicz G. (2007), Droga do zawodu. Szkolne wyzwania a proces stawania się nauczycielem, „Zarządzanie Publiczne”, 3.

Nizińska A., Kurantowicz E. (2010), Młodzi dorośli między światem szkoły a światem pracy. Polityka - badania - rekomendacje, „Forum Oświatowe”, 2(43).

Piróg D. (2013), Wybrane teorie przechodzenia absolwentów szkót wyższych na rynek pracy $w$ warunkach gospodarki opartej na wiedzy, „Prace Komisji Geografii Przemysłu Polskiego Towarzystwa Geograficznego" 23, http://prace-kgp.up.krakow.pl/article/ view/1455/1258 [dostęp: 25.05.2016].

Piróg D. (2016), Opóźnienia w przechodzeniu absolwentów szkół wyższych na rynek pracy: przyczyny, typologia, nastęstwa, „Studia Ekonomiczne. Zeszyty Naukowe Uniwersytetu Ekonomicznego w Katowicach”, 292.

Sabar N. (2004), From Heaven to Reality Through Crisis: Novice Teachers as Migrants, „Teaching and Teacher Education”, 20.

Schatz-Oppenheimer, Dvir N. (2014), From Ugly Duckling to Swan: Stories of Novice Teachers, „Teaching and Teacher Education”, 37.

Storm K.J. (2015), Teaching as Assemblage: Negotiating Learning and Practice in the First Year of Teaching, „Journal of Teacher Education”, 66(4).

Turska E. (2014), Kapital kariery ludzi młodych Uwarunkowania i konsekwencje, Wydawnictwo Naukowe Uniwersytetu Śląskiego, Katowice. 
Tynjälä P., Heikkinen H.L.T. (2011), Beginning Teachers' Transition from Pre-service Education to Working Life, ,Zeitschrift für Erziehungswissenschaft”, 14.

Walczak D. (2012), Początkujacy nauczyciele. Raport z badania jakościowego, Instytut Badań Edukacyjnych, Warszawa.

Woroniecka G. (2003), Interakcja symboliczna a hermeneutyczna kategoria przed-rozumienia, Oficyna Naukowa, Warszawa. 